\title{
Studies on Fungal Strains of Selected Regions of Ludhiana and their Biochemical Characterization
}

\author{
DEEPIKA BHATIA, SIMRANJEET SINGH, ASHISH VYAS, \\ HAKIM ISHFAQRASOOL, PARVINDER KAUR and JOGINDER SINGH*
}

Department of Biotechnology, Lovely Professional University, Phagwara (144401), Punjab, India.

http://dx.doi.org/10.12944/CWE.9.1.27

(Received: Feburary 13, 2014; Accepted: April 05, 2014)

\begin{abstract}
Conservation methods often are focused on maintaining the biodiversityof a specific landscape or ecosystem. Scientist'soften provide species richness as an indicator of biodiversity. However,species richness data are problematic when attempts are madeto enumerate microfungi, particularly those from the soil. Manysoil fungi fail to sporulate, making identification difficult.Other means of assessing the importance of fungi to ecosystempreservation must be developed. Otherwise, microfungi mightbe overlooked in discussions of ecosystem management and conservationissues. Herein, we have described the varieties of fungi was isolated from soils from high and low yield areas of a field sites of selected regions of Ludhiana. Fungal Diversity was analyzed by isolation and purification of fungal cultures. In the present investigation a total Forty Two Fungal strains have been isolated from fourteen sites of Ludhiana region. The morphological study revealed that these microbial forms have multiple occurrences at multiple sites. Finally nine fungal strains were purified and physicochemical characterized to check the effect of $\mathrm{pH}$ (3-9) and effect of temperature (25-45ㅇ $\mathrm{C}$ ) on their growth. The colony diameter was measured regularly between $24 \mathrm{hr}$ duration. Among all fungal strains maximum strains showed the maximum growth at $\mathrm{pH}-6$; while in case of other samples the maximum growth was observed in $\mathrm{pH}$ range of 3-9. All the fungal samples were grown at their optimum $\mathrm{pH}$ which has been observed to check the effect of temperature on the growth. It was observed that all the fungal strains show maximum growth at 25 $\mathrm{C}$ indicating their mesophilic nature. On the basis of morphological \& enzyme production capacity, it was found that most of the fungal strains were of Aspergillus sp. and Fusariumsp. They were potential producers of amylase and cellulose. Some strains of Aspergillus were able to produces both enzyme at the $4^{\text {th }}$ day of incubation. The cellulose production capacities were more as compared to rest of enzymes
\end{abstract}

Key words: Fungal Diversity, Sporulate, Mesophilic, Soil fungi, Physicochemical characterization.

\section{INTRODUCTION}

In a world dazzled by scientific discoveries and technological advances leading to better living standards, the negative consequence of such developments are beginning to emerge and come into focus. Microorganisms perform their metabolic processes rapidly and with remarkable specificity under ambient conditions, catalyzed by their diverse enzyme mediated reactions. Enzyme alternatives to harsh chemical technologies has led to intensive exploration of natural microbial biodiversity to discover enzyme which could function effectively and generate pollution-free "dream technologies" in the immediate future. (Srinivasan et al., 1999).

We live on "a microbial planet" (Woese, 1999) in the "Age of Bacteria" (Gould, 1996). Microorganisms, the first cellular life forms, were active on earth for more than 3.0 billion years before the development of multi-cellular, macroscopic life forms. During that time and continuing into the present, through the invention of a spectacular array of different metabolic and physiological capabilities, microbes evolved to exploit the multitude of environments and microhabitats presented by the 
abiotic world. Rapidly accumulating evidence indicates that microbe's most likely account for the vast majority of kinds of organisms on earth. Microbes carry out a stunningly diverse array of metabolic activities, several of which were instrumental in creating conditions for the evolution of other life forms.

Estimates of 1.7 million species have been described to date; estimates for the total number of species existing on earth at present vary from 5 million to nearly 100 million. Fungi are second largest group of living biota available in the world after insects. The currently known fungal species are around 72,036 species and in India 27,000 fungi were encountered (Manoharachary, 2002).

The number of fungi recorded in India exceeds 27,000 species, the largest biotic community recorded after insects (Sarbhoyet.al., 1996). The true fungi belong to kingdom Eukaryota which has 4 phyla, 103 orders, 484 families and 4,979 genera. A fungus is a member of a large group of eukaryotic organisms that includes microorganisms such as yeasts and molds, as well as the more familiar mushrooms.Fungi perform an essential role in the decomposition of organic matter and have fundamental roles in nutrient cycling and exchange. They have long been used as a direct source of food, such as mushrooms and truffles, as a leavening agent for bread, and in fermentation of various food products, such as wine, beer, and soy sauce. Since the 1940s, fungi have been used for the production of antibiotics, and, more recently, various enzymes produced by fungi are used industrially and in detergents. Fungi are also used as biological agents to control weeds and pests. Many species produce bioactive compounds called mycotoxins, such as alkaloids and polyketides, which are toxic to animals including humans. Their growth is probably related to their ability to grow at $28^{\circ} \mathrm{C}$ and produce protein and fat hydrolyzing enzymes. Soil fungi have been recognized chiefly by two methods; direct examination and isolation by cultural methods. The limitations of the first method are obvious, and although it has produced many excellent results, the physical barriers in the way of such a method limit its usefulness, and in most cases such observations as were made by it were confirmed by resort to cultural methods. In the second method, that of isolation of cultures, has been more widely used and has produced the greater numbers of species of recognized soil fungi. The substrate used in making the isolation is of prime importance in determining the species that will be taken cannot be denied. The remarkable discovery of Coker and his associates that many species of saprolegniales are seemingly present in a very wide range of soils and localities was the result of the application of the techniques and materials used to isolate this group of fungi from water samples.

Biodiversity refers to the variability of life on Earth, all the living species of animals, plants and microorganisms. According to Hawksworth (2002), fungi are a major component of biodiversity, essential for the survival of other organisms and are crucial in global ecological processes. Fungi being ubiquitous organisms occur in all types of habitats and are the most adaptable organisms. The soil is one of the most important habitats for microorganisms like bacteria, fungi, yeasts, nematodes etc. The filamentous fungi are the major contributors to the soil biomass (Alexander 1977). They form the major group of organotrophic organisms responsible for the decomposition of organic compounds. Their activity participates in the biodeterioration and biodegradation of toxic substances in the soil (Rangaswamiet al., 1999). It has been found that more number of genera and species of fungi exist in soil than in any other environment (Nagmaniet al., 2005). Contributing to the nutrient cycle and maintenance of ecosystem fungi play an important role in soil formation, soil fertility, soil structure and soil improvement (Haoquinet al., 2008). Fungi take a very important position in structure and function of ecosystem. They decompose organic matter from humus, release nutrients, assimilate soil carbon and fix organic nutrients. An intense study of abundance and diversity of soil microorganisms can divulge their role in nutrient recycling in the ecosystem.

\section{MATERIALS AND METHODS}

\section{Selection of Sample Sites}

Fourteen different sites in various villages of in and around vicinity of Ludhiana were selected as shown in table-1 (given in supplementary sheets). 


\section{Collection of soil sample}

Different types of soil samples viz. waste soil (W), dump soil (D), Leaf litter (L), decomposing organic manure $(\mathrm{M})$ etc were collected. Samples $(500 \mathrm{gm})$ were suspended in sterile polythene bag and thoroughly packaged and kept at $4^{\circ} \mathrm{C}$.

\section{Isolation of Fungi}

Samples were stored in the refrigerator at $4^{\circ} \mathrm{C}$ till the isolation of fungi. For isolating Fungi, the PDA media (solution containing all the nutrients required for the growth of microorganisms) was added with $50 \mathrm{~g} / \mathrm{ml}$ tetracycline to suppress bacterial and in the isolation plates. Medium supplemented with various chemicals components was inoculated and incubated at $28^{\circ} \mathrm{C}$.

$\begin{array}{ll}\text { Media (g/l) } & \\ \text { Potato (Peeled) } & -200 \\ \text { Dextrose } & -10 \\ \text { Agar } & -15 \\ \text { pH } & -5.6 \\ \text { Distilled Water } & -1000 \mathrm{ml}\end{array}$

\section{Purification of fungal strains}

After 4 days of incubation Fungal colony started appearing as separated on PDA medium and it was further incubated for 4 days at $28 u ́ c$. The purified colonies were aseptically picked up and transferred to PDA slants. The slants were incubated at $28^{\circ} \mathrm{C}$ for $4-5$ days for maximum growth. The slants were then stored at $4^{\circ} \mathrm{C}$ in the refrigerator.

\section{Maintenance of pure culture}

Samples were stored in the refrigerator at $\left(4^{\circ} \mathrm{C}\right)$ for the identification of fungi.

\section{Physico-chemical analysis Effect of $\mathrm{pH}$ on the growth of fungal colonies}

The fungal samples were grown at different $\mathrm{pH}$ ranges $(3,7$ and 9$)$ to check the effect of $\mathrm{pH}$ on their growth. The diameter $(\mathrm{mm})$ of the fungal colonies was measured at different time intervals.

\section{Effect of Temperature on the growth of fungal colonies}

The fungal samples were grown at different temperature ranges $\left(25^{\circ} \mathrm{C}, 35^{\circ} \mathrm{C}, 45^{\circ} \mathrm{C}\right)$ to check the effect of temperature on their growth.

\section{Bio-Chemical Screening of Samples \\ Amylase assay}

Screening was done as per the method of Behlet al., (2006) and Rele (2004). Screening of fungal culture for enzyme activity was carried out on agar media on petri plates containing $1 \%$ soluble starch. After solidification of medium around $10 \mathrm{~mm}$ well was cut out aseptically with the help of cork borer. The well was filled with crude enzyme extract and incubated at $28^{\circ} \mathrm{C}$ for $96 \mathrm{hrs}$ in an upright position. The plates were flooded with Gram's iodine solution and observations were made to see clear zone around the well. A negative control was maintained by adding heat denatured crude enzyme sample. Denaturation was done by boiling enzyme extract at $110^{\circ} \mathrm{C}$ for $20 \mathrm{~min}$ and then cooled suddenly in an ice bath for $5 \mathrm{~min}$. After flooding with Gram's iodine solution a clear area around the line of growth indicates starch hydrolysis

\section{Cellulase assay}

Screening was done as per the method of Waksman and Fred (1922). Screening of fungal culture for enzyme activity was carried out onCzapekDox Agar Medium petri plates. After solidification of medium around $10 \mathrm{~mm}$ well was cut out aseptically with the help of cork borer. The well was filled with crude enzyme extract and incubated at $28^{\circ} \mathrm{C}$ for $96 \mathrm{hrs}$ in an upright position. The plates were flooded with $0.1 \%$ Congo red dye solution andobservations were made to see clear zone around the well. A negative control was maintained by adding heat denatured crude enzyme sample. Denaturation was done by boiling enzyme extract at $110^{\circ} \mathrm{C}$ for $20 \mathrm{~min}$ and then cooled suddenly in an ice bath for $5 \mathrm{~min}$. After flooding with $0.1 \%$ Congo red dye solution a clear area around the line of growth indicates starch hydrolysis.

\section{Protease assay}

Screening was done by sub culturing of the fungus produced on skimmed milk medium one by one onto the PDA medium and were finally transferred to PDA slants and maintained at $4{ }^{\circ} \mathrm{C}$. Proteases were screened using with fungal selective media (PDA: potato dextrose agar, malt extract, Czapek and Dox medium), containing two different protein substrate, soya meal $(20 \mathrm{~g} / \mathrm{l})$ and Casein Peptone $(10 \mathrm{~g} / \mathrm{l})$. These ingredients were added to induce the protease synthesis by the fungi 
and the growth was measured after $24 \mathrm{hrs}$, 48hrs, $72 \mathrm{hrs}$ and 96hrs.

\section{Identification of Cultures}

The cultures were identified by studying their macroscopic appearance, pigmentation and growth rate (table-5 given in supplementary sheets). Visual examination was done to study the important characters such as colour, texture, macroscopic structures, growth zones, aerial and submerged hyphae and colony topography. The microscopic examination was made by observing the slide cultures after staining with Lacto phenol Cotton Blue. Based on these feature identification was made following Gilman's Manual for Fungus identification (Gilman J.C 1995).

\section{RESULTS}

Table 1: Selection of Samples Sites

\begin{tabular}{|c|c|c|}
\hline S. No. & Name of The Site & Site Code \\
\hline 1 & $\begin{array}{l}\text { Vill. KoharaTeh: } \\
\text { Distt Ludhiana }\end{array}$ & $\mathrm{KO}$ \\
\hline 2 & $\begin{array}{l}\text { Vill.JandialiTeh: } \\
\text { Distt Ludhiana }\end{array}$ & JA \\
\hline 3 & $\begin{array}{l}\text { Vill. RamgarhTeh: } \\
\text { Distt Ludhiana }\end{array}$ & RA \\
\hline 4 & $\begin{array}{l}\text { Vill. TajpurTeh: } \\
\text { Distt Ludhiana }\end{array}$ & $\mathrm{TA}$ \\
\hline 5 & $\begin{array}{l}\text { Vill. SuneetTeh: } \\
\text { Distt Ludhiana }\end{array}$ & SU \\
\hline 6 & $\begin{array}{l}\text { Vill. LaltoTeh: } \\
\text { Distt Ludhiana }\end{array}$ & LA \\
\hline 7 & $\begin{array}{l}\text { Vill. JhabewalTeh: } \\
\text { Distt Ludhiana }\end{array}$ & $\mathrm{JH}$ \\
\hline 8 & $\begin{array}{l}\text { Vill. AyaliKhurdTeh: } \\
\text { Distt Ludhiana }\end{array}$ & $\mathrm{AKH}$ \\
\hline 9 & $\begin{array}{l}\text { Vill. Ayali KalanTeh: } \\
\text { Distt Ludhiana }\end{array}$ & AKA \\
\hline 10 & $\begin{array}{l}\text { Vill. MundianKhurdTeh: } \\
\text { Distt Ludhiana }\end{array}$ & $\mathrm{MKH}$ \\
\hline 11 & $\begin{array}{l}\text { Vill. Mundian KalanTeh: } \\
\text { Distt Ludhiana }\end{array}$ & MKA \\
\hline 12 & $\begin{array}{l}\text { Vill. MangliucchiTeh: } \\
\text { Distt Ludhiana }\end{array}$ & MUC \\
\hline 13 & $\begin{array}{l}\text { Vill. BastijhodewalTeh: } \\
\text { Distt Ludhiana }\end{array}$ & BJO \\
\hline 14 & $\begin{array}{l}\text { Vill. Sunder nagarTeh: } \\
\text { Distt Ludhiana }\end{array}$ & SU \\
\hline
\end{tabular}

Physico-chemical characterization of purified fungal strains

Effect of $\mathrm{pH}$ on the growth of fungal colonies

The fungal samples were grown at different $\mathrm{pH}$ ranges (3, 7 and 9) to check the effect of $\mathrm{pH}$ on their growth. The diameter of the fungal colonies $(\mathrm{mm})$ was measured at different time intervals.

The $\mathrm{pH}$ is the symbol for the logarithm of the reciprocal of the hydrogen ion concentration $\left(\mathrm{Log} / \mathrm{H}^{+}\right)$in grams atoms per liter. The measure of the relative acidity or alkalinity of a solution is called $\mathrm{pH}$.

$\mathrm{pH}$ is one of the important factor that determines the growth \& morphology of microorganisms as they are sensitive to the concentration of hydrogen ion present in the medium. Each enzyme system of organisms has a particular $\mathrm{pH}$ range in which it can function. The $\mathrm{pH}$ value also serves as a valuable indicator of the initiation and end of the enzyme synthesis (Friedrich et al., 1989).

\section{Effect of Temperature on the growth of Fungal Colonies}

The fungal samples were grown at different temperature ranges $\left(25^{\circ} \mathrm{C}, 35^{\circ} \mathrm{C}, 45^{\circ} \mathrm{C}\right)$ to check the effect of temperature on their growth. The diameter of the fungal colonies $(\mathrm{mm})$ was measured at different time intervals.

Temperature is a vital biochemical factor which controls the enzymatic activities. Ninefungal strains were selected for temperature characterization study. Optimum temperature for the activity of Protease produced by Aspergillusniger sp., Aspergillusflavus sp., Fusarium sp.,was at 25$45^{\circ} \mathrm{C}$ respectively. The data presented in tables clearly reveals that fungal strains show maximum protease activity at $25-45^{\circ} \mathrm{C}$.Ali (1992) also recorded optimum temperature of $30^{\circ} \mathrm{C}$ for protease produced by $A$. fumigatus. Fungal strains produced proteases beyond $30^{\circ} \mathrm{C}$ but in lesser yields than that produced at optimal temperature. These temperatures might not havebeen suitable for Enzyme production. This is in accordance with the review of Daniel et al., (2010) whostated that increase in temperature led to increase inactivity 
but that there was limit to the increase in activitybecause higher temperatures led to a sharp decrease in activity. This could be due to the denaturing of protein structure.

Purified fungal strains were physicochemical characterized to check the effect of $\mathrm{pH}(3-9)$ and effect of temp. (25-45으. $\mathrm{C}$. Effect of $\mathrm{pH}$ on the growth of fungi indicates that the fungal strainswere shown the maximum growth at acidic $\mathrm{pH}$ i.e3. Some strains of Aspergillus were shown maximum growth at alkaline $\mathrm{pH}-9$. They show the maximum growth at $4^{\text {th }}$ day of incubation with slight decrease afterwards. A pH gradient agar plates with surface $\mathrm{pH}$ ranging from about 3-9 was easily prepared. The gradient was sufficiently stable to permit different growth characteristics among various fungal species at different $\mathrm{pH}$ value to be distinguished. The $\mathrm{pH}$ effects on the growth rate, conidiogenisis and pigment formation were consistent with the results obtained by other workers. Wheeler et al., (1990) reported that the effect of $\mathrm{pH}$ on growth rate of 61 isolates of fungi. Four species of Aspergillus grows over the $\mathrm{pH}$ range 3-9 and temperature $37^{\circ} \mathrm{C}$. in general Aspergillus were the most tolerant of alkaline $\mathrm{pH}$. The temperature effect on fungal strains was studied at their observed optimum $\mathrm{pH}$ values from 3.0 - 9.0 and at different temperature ranging from (25$45^{\circ} \mathrm{C}$ ). Optimum temperature was found to be $25^{\circ} \mathrm{C}$ for all the fungal strains. The result clearly indicates the presence of mesophilic strains of Aspergillus and Fusarium sp. The maximum growth was found to be occurs at the $4^{\text {th }}$ day of incubation. Gradually on increasing temperature up to $45^{\circ} \mathrm{C}$, the growth decreases afterwards. The colony diameter was measured regularly after the gap of $24 \mathrm{hrs}$ at different temperature range.

Table 2: Effect of different $\mathrm{pH}$ range on the growth of fungal sp

\begin{tabular}{|c|c|c|c|c|c|c|c|c|c|}
\hline \multirow[t]{2}{*}{ Time } & \multicolumn{3}{|c|}{$\begin{array}{c}\text { Aspergillus glaucus } \\
\text { pH- }\end{array}$} & \multicolumn{3}{|c|}{$\begin{array}{c}\text { Aspergillus fumigatus } \\
\mathrm{pH}-\end{array}$} & \multicolumn{3}{|c|}{$\begin{array}{c}\text { Fusarium sp } \\
\text { pH- }\end{array}$} \\
\hline & pH-3 & $\mathrm{pH}-7$ & $\mathrm{pH}-9$ & $\mathrm{pH}-3$ & pH-7 & pH-9 & pH-3 & pH-7 & pH-9 \\
\hline $24 \mathrm{hrs}$ & 0 & 2 & 2 & 0 & 1.5 & 0.5 & 0 & 2.5 & 2.5 \\
\hline $48 \mathrm{hrs}$ & 0 & 3.5 & 3 & 0 & 2.5 & 2.5 & 0 & 3.5 & 5.8 \\
\hline $72 \mathrm{hrs}$ & 0.5 & 4.8 & 7.5 & 0 & 4.5 & 4.5 & 0 & 4.8 & 7 \\
\hline $96 \mathrm{hrs}$ & 1 & 9.5 & 10.5 & 0 & 11.5 & 6.5 & 1.5 & 9 & 8.5 \\
\hline \multirow[t]{2}{*}{ Time } & \multicolumn{3}{|c|}{$\begin{array}{c}\text { Fusarium sp. } \\
\mathrm{pH}\end{array}$} & \multicolumn{3}{|c|}{$\begin{array}{c}\text { Aspergillus nidulans } \\
\mathrm{pH}\end{array}$} & \multicolumn{3}{|c|}{$\begin{array}{c}\text { Fusarium sp } \\
\mathrm{pH}\end{array}$} \\
\hline & pH-3 & $\mathrm{pH}-7$ & $\mathrm{pH}-9$ & pH-3 & $\mathrm{pH}-7$ & pH-9 & $\mathrm{pH}-3$ & $\mathrm{pH}-7$ & $\mathrm{pH}-9$ \\
\hline $24 \mathrm{hrs}$ & 0 & 0 & 1.5 & 0 & 2 & 2.5 & 0 & 2.5 & 2.5 \\
\hline $48 \mathrm{hrs}$ & 0 & 0 & 3 & 0 & 2.8 & 5.5 & 0 & 3.5 & 5.8 \\
\hline $72 \mathrm{hrs}$ & 0 & 2 & 5 & 0.8 & 6 & 6.5 & 0 & 4.8 & 7 \\
\hline $96 \mathrm{hrs}$ & 2.5 & 3.5 & 7.5 & 2 & 9.5 & 8 & 1.5 & 9 & 8.5 \\
\hline \multirow[t]{2}{*}{ Time } & \multicolumn{3}{|c|}{$\begin{array}{c}\begin{array}{c}\text { Fusarium sp. } \\
\text { pH- }\end{array} \\
\end{array}$} & \multicolumn{3}{|c|}{$\begin{array}{l}\text { Aspergillus flavus } \\
\text { pH- }\end{array}$} & \multicolumn{3}{|c|}{$\begin{array}{c}\text { Aspergillus niger } \\
\text { pH- }\end{array}$} \\
\hline & pH-3 & pH-7 & pH-9 & $\mathrm{pH}-3$ & $\mathrm{pH}-7$ & $\mathrm{pH}-9$ & pH-3 & $\mathrm{pH}-7$ & $\mathrm{pH}-9$ \\
\hline $24 \mathrm{hrs}$ & 0 & 0 & 1.5 & 0 & 1.5 & 0.5 & 0 & 2 & 1 \\
\hline $48 \mathrm{hrs}$ & 0 & 0 & 3 & 0 & 3 & 3 & 0 & 2.8 & 2.5 \\
\hline $72 \mathrm{hrs}$ & 0 & 2 & 5 & 1.5 & 7.5 & 7.5 & 0 & 6 & 4 \\
\hline 96hrs & 2.5 & 3.5 & 7.5 & 1.8 & 10.5 & 11 & 0.5 & 11 & 7 \\
\hline
\end{tabular}


Table 3: Effect of temperature on the growth of fungal sp. at selective pH

\begin{tabular}{|c|c|c|c|c|c|c|c|c|c|}
\hline \multirow[t]{3}{*}{ Time } & \multicolumn{3}{|c|}{$\begin{array}{l}\text { Aspergillus glaucus } \\
\text { Temp at } \mathrm{pH}-9\end{array}$} & \multicolumn{3}{|c|}{$\begin{array}{l}\text { Aspergillus fumigatus } \\
\text { Temp at } \mathrm{pH}-8\end{array}$} & \multicolumn{3}{|c|}{$\begin{array}{l}\text { Fusarium sp } \\
\text { Temp at pH-6 }\end{array}$} \\
\hline & pH-3 & $\mathrm{pH}-7$ & $\mathrm{pH}-9$ & $\mathrm{pH}-3$ & pH-7 & $\mathrm{pH}-9$ & $\overline{\mathrm{pH}-3}$ & $\mathrm{pH}-7$ & $\mathrm{pH}-9$ \\
\hline & $25^{\circ} \mathrm{C}$ & $35^{\circ} \mathrm{C}$ & $45^{\circ} \mathrm{C}$ & $25^{\circ} \mathrm{C}$ & $35^{\circ} \mathrm{C}$ & $45^{\circ} \mathrm{C}$ & $25^{\circ} \mathrm{C}$ & $35^{\circ} \mathrm{C}$ & $45^{\circ} \mathrm{C}$ \\
\hline $24 \mathrm{hrs}$ & 9 & 4.5 & 1.5 & 6.5 & 6.5 & 2.5 & 5 & 4 & 4 \\
\hline $48 \mathrm{hrs}$ & 15 & 7.5 & 3 & 12 & 11 & 4 & 13 & 7.5 & 4.5 \\
\hline $72 \mathrm{hrs}$ & 22 & 15 & 5.5 & 20.5 & 15.5 & 6.5 & 24 & 13 & 8.5 \\
\hline $96 \mathrm{hrs}$ & 30 & 17.5 & 12 & 30 & 22 & 11.5 & 33.5 & 18.5 & 13.5 \\
\hline \multirow[t]{3}{*}{ Time } & \multicolumn{3}{|c|}{$\begin{array}{l}\text { Fusarium sp. } \\
\text { Temp at } \mathrm{pH}-8\end{array}$} & \multicolumn{3}{|c|}{$\begin{array}{l}\text { Aspergillus nidulans } \\
\text { Temp at } \mathrm{pH}-6\end{array}$} & \multicolumn{3}{|c|}{$\begin{array}{l}\text { Fusarium sp } \\
\text { Temp at } \mathrm{pH}-6\end{array}$} \\
\hline & pH-3 & $\mathrm{pH}-7$ & pH-9 & $\mathrm{pH}-3$ & pH-7 & pH-9 & pH-3 & $\mathrm{pH}-7$ & $\mathrm{pH}-9$ \\
\hline & $25^{\circ} \mathrm{C}$ & $35^{\circ} \mathrm{C}$ & $45^{\circ} \mathrm{C}$ & $25^{\circ} \mathrm{C}$ & $35^{\circ} \mathrm{C}$ & $45^{\circ} \mathrm{C}$ & $25^{\circ} \mathrm{C}$ & $35^{\circ} \mathrm{C}$ & $45^{\circ} \mathrm{C}$ \\
\hline $24 \mathrm{hrs}$ & 7 & 3.5 & 3.5 & 8 & 2.5 & 4 & 3.5 & 3.5 & 4 \\
\hline $48 \mathrm{hrs}$ & 13 & 11.5 & 4.4 & 15.5 & 6.5 & 5 & 13.5 & 7.5 & 5 \\
\hline $72 \mathrm{hrs}$ & 25 & 15 & 10 & 17.5 & 10 & 7.5 & 18 & 15 & 6.5 \\
\hline $96 \mathrm{hrs}$ & 40 & 16.5 & 12.5 & 24 & 14 & 14.5 & 26 & 18.5 & 11 \\
\hline \multirow[t]{3}{*}{ Time } & \multicolumn{3}{|c|}{$\begin{array}{l}\text { Fusarium sp. } \\
\text { Temp at } \mathrm{pH}-8\end{array}$} & \multicolumn{3}{|c|}{$\begin{array}{c}\text { Aspergillus flavus } \\
\text { Temp at } \mathrm{pH}-6\end{array}$} & \multicolumn{3}{|c|}{$\begin{array}{l}\text { Aspergillus niger } \\
\text { Temp at } \mathrm{pH}-6\end{array}$} \\
\hline & pH-3 & $\mathrm{pH}-7$ & pH-9 & $\mathrm{pH}-3$ & $\mathrm{pH}-7$ & $\mathrm{pH}-9$ & pH-3 & $\mathrm{pH}-7$ & $\mathrm{pH}-9$ \\
\hline & $25^{\circ} \mathrm{C}$ & $35^{\circ} \mathrm{C}$ & $45^{\circ} \mathrm{C}$ & $25^{\circ} \mathrm{C}$ & $35^{\circ} \mathrm{C}$ & $45^{\circ} \mathrm{C}$ & $25^{\circ} \mathrm{C}$ & $35^{\circ} \mathrm{C}$ & $45^{\circ} \mathrm{C}$ \\
\hline $24 \mathrm{hrs}$ & 8.5 & 5 & 5 & 8.5 & 4.5 & 6.5 & 10.5 & 4.5 & 7.5 \\
\hline $48 \mathrm{hrs}$ & 12.5 & 11.5 & 7.5 & 15 & 6.5 & 8.5 & 12.5 & 6.5 & 9.5 \\
\hline $72 \mathrm{hrs}$ & 24 & 13.5 & 9 & 27 & 11 & 11.5 & 25 & 9.5 & 12.5 \\
\hline 96hrs & 36.5 & 16 & 14 & 32 & 15.5 & 15.5 & 34 & 14 & 16.5 \\
\hline
\end{tabular}

Table 4: Enzymatic screening of purified fungal strains [Colony diameter $(\mathrm{mm})$ was measured]

\begin{tabular}{|c|c|c|c|c|}
\hline $\begin{array}{l}\text { S. } \\
\text { no. }\end{array}$ & $\begin{array}{l}\text { Identified } \\
\text { Fungal Strain }\end{array}$ & $\begin{array}{l}\text { Amylase Screening } \\
\text { Starch Hydrolysis Test }\end{array}$ & $\begin{array}{l}\text { Cellulase Screening } \\
\text { Congo Red Dye Test }\end{array}$ & $\begin{array}{l}\text { Protease } \\
\text { Screening }\end{array}$ \\
\hline 1 & Aspergillus glaucus & $+(1.5 \mathrm{~mm})$ & $+(2.0 \mathrm{~mm})$ & - \\
\hline 2 & Aspergillus fumigatus & & $+(1.0 \mathrm{~mm})$ & $+(8.5 \mathrm{~mm})$ \\
\hline 3 & Fusarium sp. & $+(1 . \overline{5} \mathrm{~mm})$ & $+(2.0 \mathrm{~mm})$ & $+(9.5 \mathrm{~mm})$ \\
\hline 4 & Fusarium sp. & $+(1.0 \mathrm{~mm})$ & $+(2.0 \mathrm{~mm})$ & $+(9.0 \mathrm{~mm})$ \\
\hline 5 & Aspergillus nidulans & - & - & $+(10.5 \mathrm{~mm})$ \\
\hline 6 & Fusarium sp. & $+(1 . \overline{5} \mathrm{~mm})$ & $+(2 . \overline{0} \mathrm{~mm})$ & $+(8.0 \mathrm{~mm})$ \\
\hline 7 & Aspergillusf lavus & $+(1.5 \mathrm{~mm})$ & $+(1.5 \mathrm{~mm})$ & $+(7.5 \mathrm{~mm})$ \\
\hline 8 & Aspergillus niger & $+(1.0 \mathrm{~mm})$ & $+(2.0 \mathrm{~mm})$ & $+(8.0 \mathrm{~mm})$ \\
\hline 9 & Fusarium sp. & $+(2.5 \mathrm{~mm})$ & $+(2.0 \mathrm{~mm})$ & $+(8.0 \mathrm{~mm})$ \\
\hline
\end{tabular}




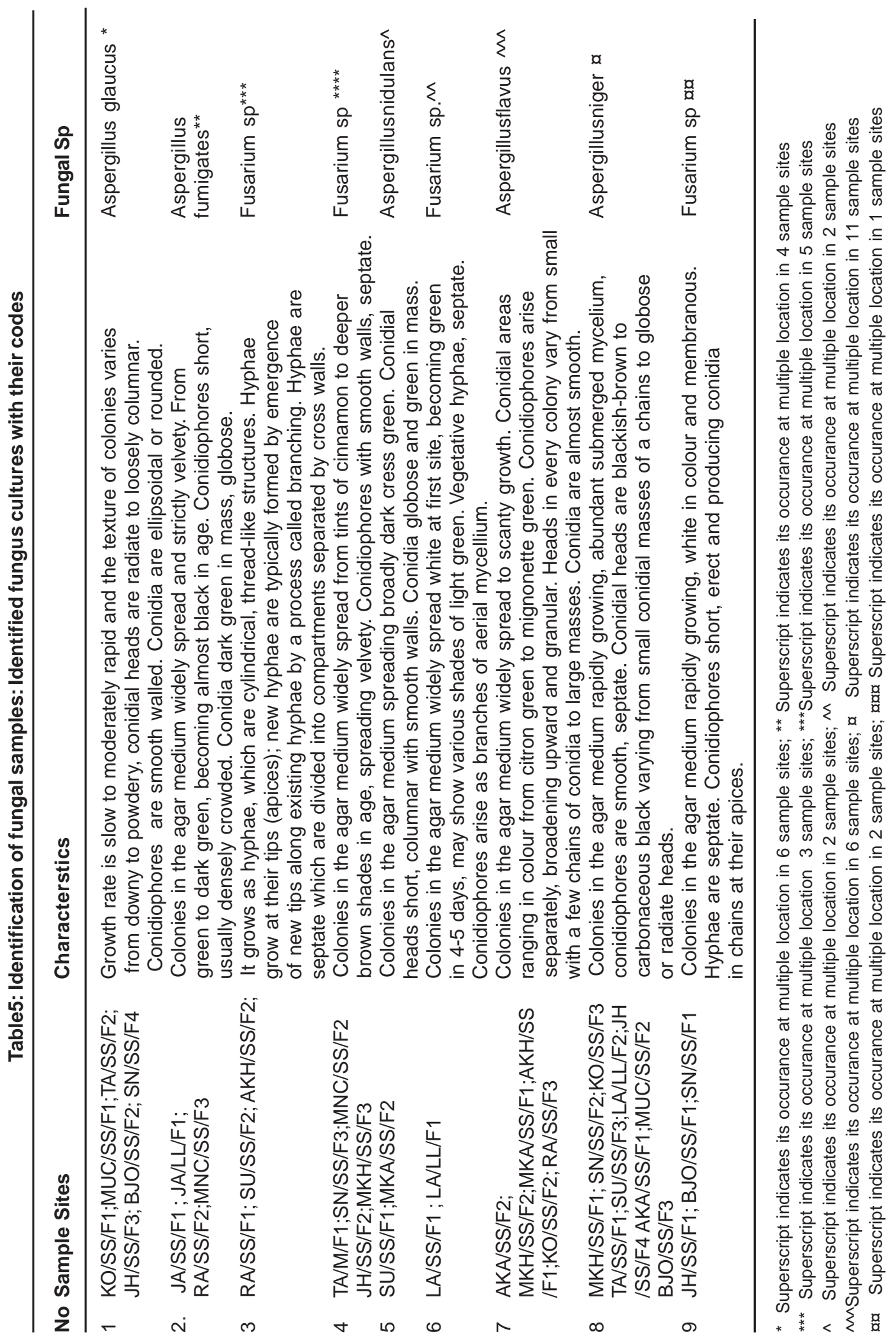



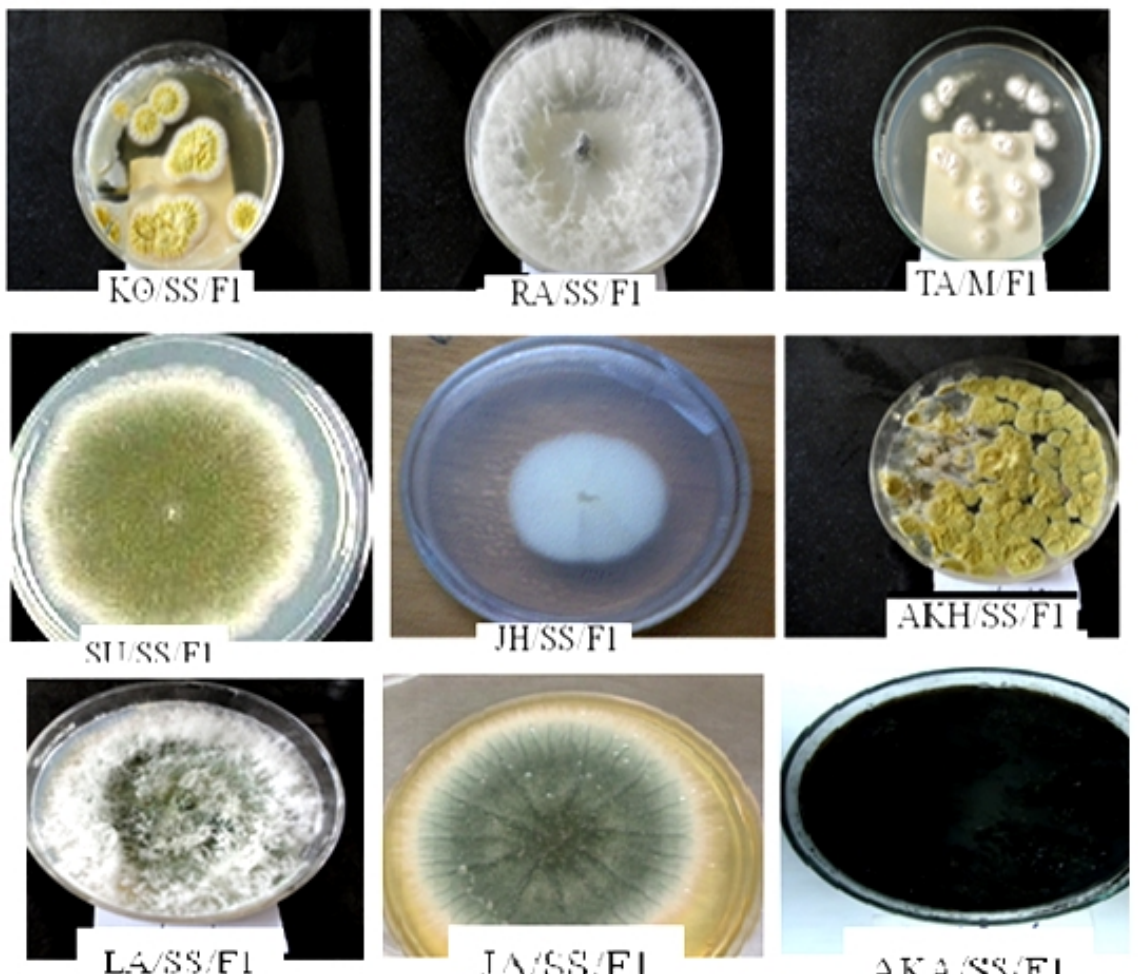

$\mathrm{T} \triangle \mathrm{SS} \mathrm{F \perp}$

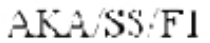

Fig. 1
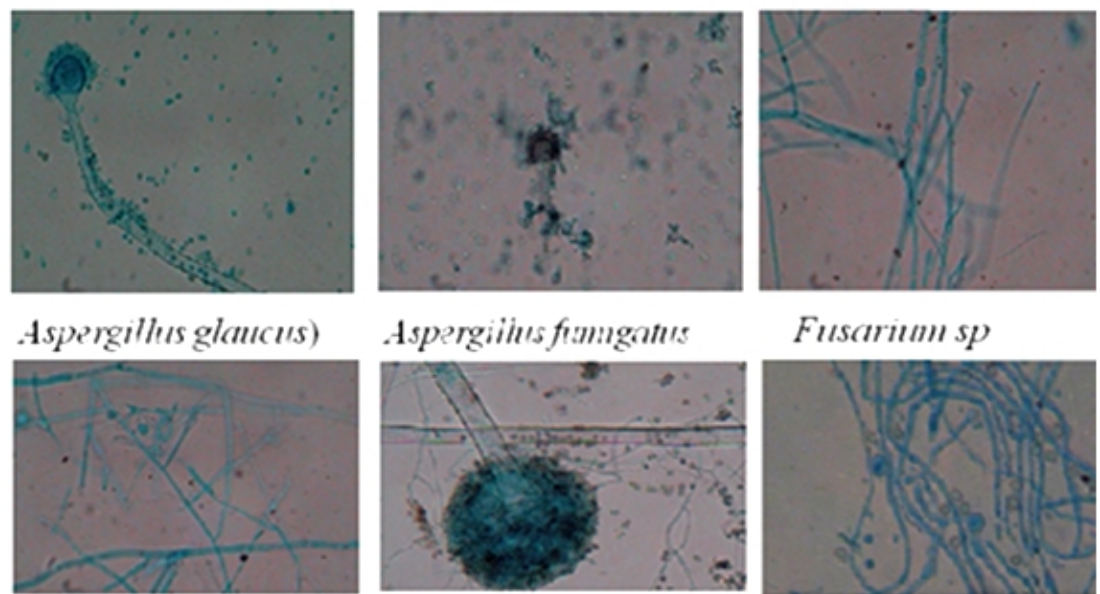

Aspergiilus fiangatus

Fusaritm sp
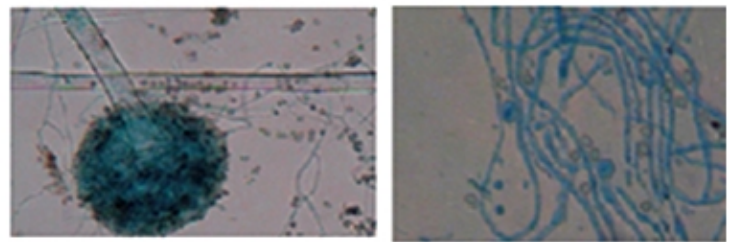

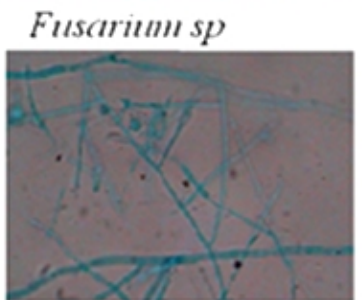

Fusarium! sp
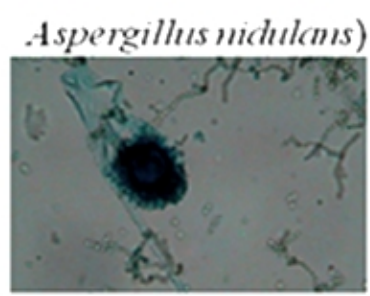

Aspergillus flawis

Fig. 2

\section{Fllsaritn! sp}

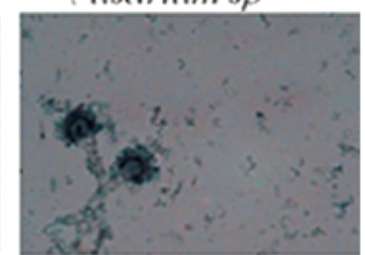

Aspergillus miger 


\section{Enzymatic screening of purified fungal strains}

Enzymes are the most important products obtained for human needs through microbial sources. Enzymes are highly efficient environmental friendly protein catalyst synthesized by living systems. They have significant advantage over

\section{Amylase screening of purified fungal strains}

(2)

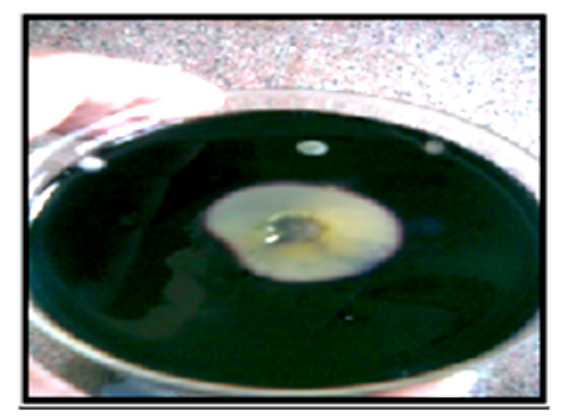

chemical catalyst in terms of catalytic activity, ability to work at moderate temperature and the ability to get produced in large amounts (Chand \& Mishra, 2003). Dr. JockichiTakamine (1914) was the first indiviual to realize the mechnical possibility of cultivated enzymes and presented them to society. Although he was mainly concerned with fungal

(b)

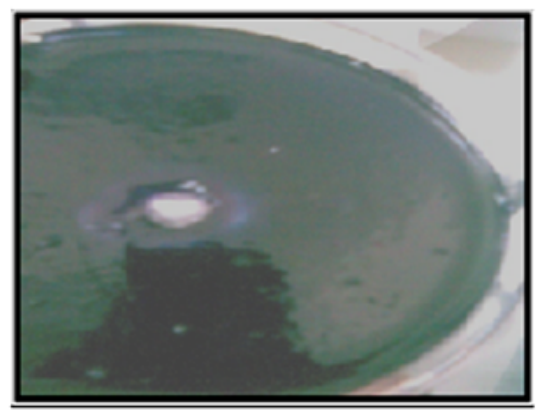

Image Results for Comparison between Zone of Inhibition (a) \& Control (b)

\section{Cellulase screening of purified fungal strains}

(a)

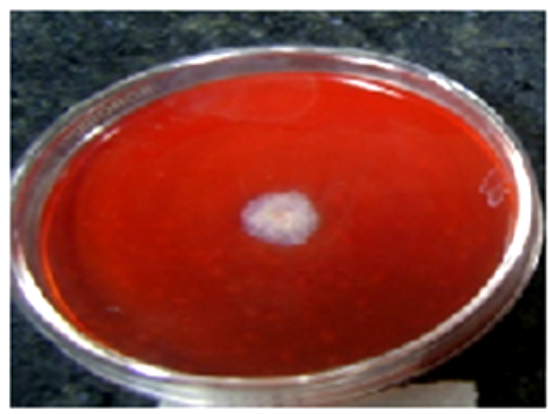

Image Results for Comparison between Zone of hhibition (a) \& Control (b) (b)

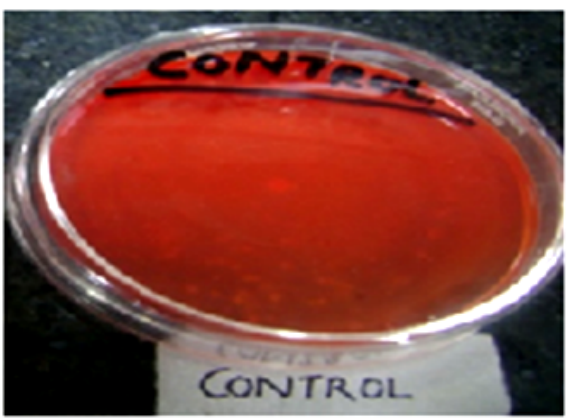

Protease screening of purified fungal strains

(a)

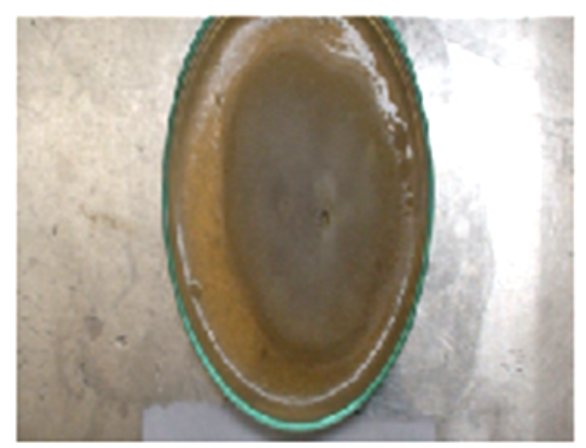

(b)

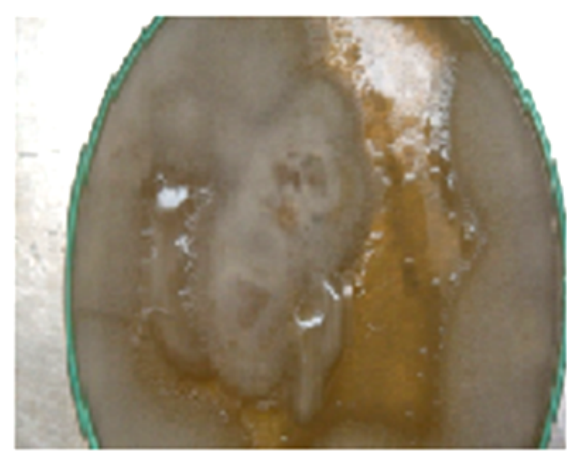

Image Results for Protea se activity (growth in $\mathrm{mm}$ ) 
enzymes, Boidin and Effront (1917) were pioneers in the output of enzymes produced by bacteria. Since that time microbial enzymes have taken the place of enzymes from plants and animals (Underkofler, et al. 1957).

A total of 9 fungal strains were purified from different soil samples and enzymatic screening was performed at optimum $\mathrm{pH}$ and temperature. The results indicate that number of microbial forms has multiple occurrences and additionally, they have the capacity to produce amylase under optimum environmental conditions. All the purified fungal strains were screened for the enzyme production capacity viz. amylase, cellulase and protease at their recorded optimum $\mathrm{pH}$ and temperature. Most of the strains were potential producer of cellulase among all. Maximum enzyme synthesis occurred at the $4^{\text {th }}$ day of incubation with gradual decrease afterwards. The $\mathrm{pH}$ and temperature effects the enzyme activity of fungal strains. The strains of Aspergillus and Fusarium sp. were the maximum producer of enzymes.

Chellapandi (2009) reported Aspergillusflavusand Aspergillusterreusas the potential strains for production oftannery protease in submerged fermentation. To improve the productivity of protease enzyme in liquid broth, various media ingredients have been optimized. The crude and partially purified proteases preliminarily characterized and used for unhairing processes at lab scale in tannery. The protease obtained from these strains showed the good activity in wide alkaline condition at $50 \stackrel{\circ}{\circ} \mathrm{C}$ suggesting the possibility of using in leather and detergent industry.

Result also raises hope for purification and applications in various industrial processes. This can have important implications in proteolytic breakdown of proteins by these fungal strains for the establishment of a robust and cost effective process in various industries like brewing,baking, textiles and laundry etc.

The present study raises the hope to further characterize these fungal strains for enzymatic characterization and to be harnessed for industrial applications.

\section{DISCUSSION}

The major goal of microbial ecology is to understand microbial diversity in natural habitats; therefore knowledge of both microorganisms and habitats is essential. A Total of 14 Sites were selected for sample collection for the isolation of the fungal strains, quantitatively the number of fungal cultures were large has been shown in table 1 and 2 respectively. A total of forty two fungal cultures were isolated from fourteen sample sites. After critical morphological observation (Colony colour, Colony shape, pigmentation, pattern of growth in five days) and microscopic observation, many of the fungal cultures were found to be similar and found to be present at multiple locations and indicated by different superscripts. Identified fungal strains are, Aspergillus fumigatus, Aspergillus glaucaus, Aspergillus nidulans, Fusarium sp., Aspergillus niger. The results show that the region Ludhiana is flourished with microbial flora. The above results also confirm the isolation studies earlier done by Goyalet al 2008, Jain et al 2005. The effect of $\mathrm{pH}$ on the growth of Aspergillus glaucaus and Aspergillus fumigatus showed maximum growth at $\mathrm{pH}-9$ (alkaline $\mathrm{pH}$ ). The colony diameter was measured i.e $11.5 \mathrm{~mm}$. The growth increases after 48hrs. Sporulation was observed after $96 \mathrm{hrs}$. Aspergillus flavus shows that the optimum $\mathrm{pH}$ was recorded i.e acidic $\mathrm{pH}-6$. The colony diameter was measured 12.5 after 96 hrs. Green colored spores was observed microscopically after $48 \mathrm{hrs}$. Similar results were observed with the fungal strains. The optimum $\mathrm{pH}$ was 6 \& the colony diameter measured i.e 12.5. Sporulation was observed after $96 \mathrm{hrs}$. The data presented in Table 1 \& 2 indicates that Aspergillusfumigatus grows maximally at $25^{\circ} \mathrm{C}$ at alkaline $\mathrm{pH}$ i.e 8 . The colony diameter was measured after the gap of $24 \mathrm{hrs}$. The maximum colony diameter recorded $30 \mathrm{~mm}$ after $96 \mathrm{hrs}$ at $25^{\circ} \mathrm{C}$. The mesophilic fungal strain, Aspergillusfumigatus which grows at $25^{\circ} \mathrm{C}$ at acidic $\mathrm{pH}$ (i.e 6). The growth rate decreases when temperature increases up to $45^{\circ} \mathrm{C}$. It clearly depicts that the optimum temperature was found to be $25^{\circ} \mathrm{C}$ at $\mathrm{pH} 8$ for the growth of Fusarium sp. The highest colony diameter was measured i.e $40 \mathrm{~mm}$ after 96 hrs. the presence of mesophilic fungal strain of Aspergillusnidulans. The fungal sample were 
allowed to grow at its optimum $\mathrm{pH}$ (i.e 6). The optimum temperature found to be recorded was $25^{\circ} \mathrm{C}$ and highest colony diameter was $24 \mathrm{~mm}$. The strain of Aspergillusflavus\&Aspergillusniger. The optimum temperature was found to be $25^{\circ} \mathrm{C}$ at acidic $\mathrm{pH}$ (i.e 6). Very less growth was observed after increasing temperature up to $45^{\circ} \mathrm{C}$.

\section{REFERENCES}

1. Alexander $\mathrm{M}$, Introduction to soil Microbiology, John Wiley \&Sons, New York. (1977).

2. Ali gao, Formation of protease by Aspergillusfumigatusand Penicilliumspp. J. King Saud Univ. Sci., 4(2):127 (1992).

3. Behal, A., Singh, J., Sharma, MK., Puri, P and Batra, N, Characterisation of á- amylase from Bacillus sp. AB 04. Int J Agric and Biol. 8(1) : 80-83 (2006).

4. Chand, S and Mishra, P., Research and application of microbial enzymes- India's contribution. AdvBiochemEnginBiotechnol. 85: 95-124 (2003).

5. Chellapandi. P., Production and Preliminary Characterization ofAlkaline Protease from Aspergillus flavus and Aspergillu sterreus. E-Journal of Chemistry, 7(2):479-482 (2009).

6. Daniel RM, Peterson ME, Danson MJ, The molecular basis of the effect of temperature on enzyme activity. Biochem. J., 425(2): 353360 (2010).

7. Friedrich J., Cimerman, A., Steiner, W., Submerged production of pectinolytic enzymes by Aspergillusniger: Effect of different aeration/agitation regimes. Appl Microbiol Biotechnol. 31: 421-442 (1989).

8. Gould S J, "Planet of Bacteria," Washington Post Horizon, 119 (344) (1996).

9. GoyalMeenakshi, Kalra KL, Sareen VK, Soni. G, Xylanase Production With Xylan rich lignocellulosic Waste by alocal soil isolate of Trichoderma viride Brazilian Journal of Microbiology. 39: 535-541 (2008).

10. Gilman JC, A Manual of Soil Fungi, $2^{\text {nd }}$ Indian Edition, Biotech Books Delhi (1995).

11. Hao-quin Pan, Jin- Feng Yu, Yue- ming Wu, Tian- Yu Zhang \& Hong- Feng Wang, Area: 1, J. Zhejiang Univ. Sci., B 9(10): 829-834 (2008).

12. Hawksworth, DL, The magnitude of fungal diversity: the 1.5 million species estimate revisited. Mycological Research 105: 14221432 (2002).

13. Jain Sandeep, Verma .KS, Shah Mehraj, Pathological studies on Alternaria alternate (Fr.) Keiss, causing Leaf Blight of Pear. Plant pathology Journal 4(1): 51-53 (2005).

14. Manoharachary, C., Biodiversity, Conservation and Biotechnology of Fungi. Presidential Address, Section-Botany, 89th Session of Indian Science Congress, Lucknow (2002).

15. Nagmani A, IK Kunwar, C. Manoharachary, Handbook of Soil Fungi. Published by I. K. International Pvt, Ltd. New Delhi (2005).

16. Rele, MV., Biodiversity and Germplasm Collection of Alkaliophilic Fungi and Actinomycetes For Biotechnology Applications. Project Report, National Chemical Laboratories, Pune (2004).

17. Rangaswami G. \& Bagyaraj DJ, Agricultural Microbiology II edition published by Prentice Hall of India Pvt. Ltd. N. Delhi (1998).

18. Sarbhoy, AK., Agarwal, DK. and Varshney, J. L., Fungi of India1982-1992, CBS Publishers and Distributors, New Delhi, pp. 350 (1996).

19. Srinivasan, M.C., Rele, M.V. and Ingale, S., PNAS B65. 3 \& 4, 143-162 (1999).

20. Underkofler, LA., Barton RR, and Rennert SS, Production of Microbial Enzymes and Their Applications. Appl Microbiology 6(3): 212-221 (1957).

21. Wheeler A. Kathryn ,Hurdman F. Beverly and Pitt JI, Influence of $\mathrm{pH}$ on the growth of some toxigenic species of Aspergillus, Penicillium and Fusarium. International journal of food microbiology, 141-149 (2002)

22. Woese CR, The quest for Darwin's grail ASM News 65: 260-263 (1999).

23. Waksman, SA. and Fred EB, A tentative outline of the plate method for determining the number of microorganisms in the soil. Soil Sci., 14: 27-28 (1922). 